\title{
TOLERANSI AGAMA DAN MOTIF MISI KRISTEN
}

\author{
Dewi Magdalena Rotua
}

\begin{abstract}
PENDAHULUAN
Bangsa Indonesia merupakan bangsa yang amat heterogen penduduknya. Kondisi tersebut sangat didukung oleh penyebaran penduduk yang beragam serta letak geografis yang didominasi oleh kepulauan. Keadaan ini membentuk kristalisasi budaya, agama, bahasa, dan etnis yang cenderung membangkitkan otonomi kedaerahan yang radikal. Pada sisi lain, bangsa Indonesia sudah terbiasa hidup dalam kemajemukan. Hal tersebut dapat diamati dengan beragamnya bangsa Indonesia yang terdiri dari berbagai suku, bahasa, budaya, agama dan beribu-ribu pulau. Kemajemukan ini membuat bangsa Indonesia amat familiar dengan kepelbagaian. Kendatipun demikian kemajemukan tersebut acapkali menimbulkan friksi dan konflik antara sesama anak bangsa, baik yang kelihatan maupun yang tersembunyi. Berkaitan dengan hal itu, Victor Tanya memberi komentar dengan menegaskan bahwa konflik ini telah mengakibatkan bukan saja kehancuran fisik dan kematian dalam jumlah yang sangat besar, tetapi yang lebih berbahaya ialah telah mengancam peradaban umat manusia. ${ }^{1}$ Jika kondisi tersebut menyatakan situasi yang sesungguhnya, maka sejauh mana Gereja dan orang Krisen dapat bertoleransi dengan berbagai agama yang ada di tanah air ini? Apakah toleransi yang kita lakukan hanyalah dalam bidang sosial ataukah menyangkut berbagai isu-isu penting dalam doktrin Kristen, agar kita dapat hidup dengan harmonis dalam masyarakat majemuk ini? Bagaimana seharusnya kita bersikap terhadap berbagai agama yang ada di Indonesia ini? Hal-hal tersebut merupakan pekerjaan rumah yang harus diselesaikan oleh Gereja atau orang Kristen.

Permasalahan yang telah dipaparkan di atas mendorong penulis mencoba untuk meneliti tentang Toleransi Agama dan Motif Misi Kristen sebagai upaya memberi kontribusi pemikiran kritis dan dorongan praktis terhadap respons dan perilaku yang kurang tepat dalam memahami peran Gereja dalam Dunia. Tentu materi yang akan dibahas bukanlah sesuatu
\end{abstract}

${ }^{1}$ Victor I. Tanya, Pluralisme Agama dan Problema Sosial (Jakarta: PT. Pustaka Cidesindo,1998), XIX. 
yang baru, bahkan sangat mungkin bahwa penelitian tentang hal tersebut telah pernah dikemukakan sebelumnya secara lebih rinci.

Menyadari luasnya cakupan tentang permasalahan dan pembahasan mengenai materi Toleransi Agama dan Motif Misi Kristen, maka penulis membatasi pemaparan pada pada beberapa bagian saja. Dalam makalah ini penulis akan memaparkan toleransi beragama dan motif misi Gereja di Indonesia. Adapun materi yang akan dipaparkan adalah, Pertama, penjelasan tentang pengertian toleransi dan agama. Selanjutnya pemaparan tentang dinamika bertoleransi di Indonesia, urgensi toleransi beragama, peran Pancasila sebagai dasar negara, keunikan pluralitas, tantangan pluralisme. Selanjutnya memaparkan mengenai motif misi Kristen serta dialog Kristen sebagai sarana dalam toleransi agama, serta bagian penutup adalah kesimpulan.

\section{PENGERTIAN TOLERANSI DAN AGAMA}

Toleransi merupakan satu sikap yang sangat diperlukan ketika kita hidup di tengah-tengah masyarakat yang majemuk dan secara khusus dalam kemajemukan agama. Berkaitan dengan hal itu, Breward menyatakan bahwa toleransi dapat memperkaya agama-agama yang ada. Ia mengemukakan bahwa, "Toleransi ialah bukan hanya pengakuan suatu komunitas mengenai keberadaan agama yang pluralis, melainkan juga menyakini agama yang pluralitas dapat memperkaya satu dengan yang lain." Toleransi diartikan oleh Peter Salim sebagai tenggang rasa, sikap membiarkan, sikap mentolelir. ${ }^{3}$ Webster mengemukakan toleransi sebagai berikut: a sympathy or indulgence for beliefs or practices differing from or conflicting with one's own or the act of allowing something. ${ }^{4}$ Sedangkan J.E. Wood menjelaskan toleransi: Indulgence of belief or conduct other than one's own. ${ }^{5}$ Dari pengertian toleransi yang telah dikemukakan di atas toleransi merupakan satu sikap menerima atau menghargai kepelbagaian. Dengan kata lain dapat digambarkan toleransi memberi kesempatan yang

\footnotetext{
2 I.Breward, "Toleration" in New Dictionary of Theology, Sinclair B. Ferguson (ed.) (Leicester: Inter Varsity Press, 1988), 689

3 Peter Salim, The Contemporary English-Indonesian Dictionary (Jakarta: Modern English Press, 1985), 2073

${ }^{4}$ Webster, "Toleration" in Webster's New Collegiate Dictionay (Massachusetts: Phoenix Press Inc, 1973), 1228

${ }^{5}$ J. E. Wood , "Tolerance" in Evangelical Dictionary of Theology, Walter Elwell (ed)., (Grand Rapids, Michigan: Baker Book House,1984), 1098
} 
luas bagi setiap penganut agama untuk mengembangkan sikap toleransi, dalam artian perlunya sikap saling menghormati dan memahami diantara masing-masing penganut agama. Berkaitan dengan hal itu, Viktor Tanya menjelaskan bahwa sikap toleransi adalah memberlakukan agama lain dengan penuh hormat. Ia menyatakan sebagai berikut:

Toleransi berarti endurance atau ketabahan, yang bukan hanya menunjuk pada sikap membiarkan orang lain hidup di sekitar kita tanpa larangan dan penganiayaan. Toleransi dalam artian seperti ini khususnya di bidang agama menunjuk pada kerelaan dan kesediaan untuk memasuki dan memberlakukan agama lain dengan penuh hormat dalam suatu dialog dengan orang lain secara terus-menerus tanpa perlu dipengaruhi oleh pendapat lain dalam dialog tersebut. ${ }^{6}$

Arah pengertian toleransi yang diutarakan di atas pada dasarnya lebih mengacu pada suatu sikap hidup yang dilakukan oleh seseorang atau suatu komunitas dalam suatu kemajemukan. Alister McGrath mengakui hal ini dengan mengemukakan: Toleration is much more likely to result from showing respect to other religions, than from forcing them into an artificial framework. ${ }^{7}$ Dalam arah yang sama Stevri Lumintang memberi komentar bahwa, "toleransi agama tidak hanya membutuhkan keterbukaan, melainkan juga kejujuran untuk mengakui perbedaan, menampilkan perbedaan dan kelebihan yang satu daripada yang lain. Toleransi agama juga memerlukan sikap hati yang dewasa, artinya menerima atau mengakui apabila orang beragama lain lebih kaya dalam pemahaman dan pengalaman agamanya, lebih indah dan teguh keyakinan agamanya."8 Kendatipun demikian toleransi tidak selalu memiliki asumsi menerima dan mengadopsi secara utuh keyakinan atau agama orang lain, seperti yang diungkapkan oleh Efferin, dengan memaparkan, "Jadi dalam memahami toleransi, kita perlu membedakan antara menerima seseorang yang berbeda pandangan atau agama dengan menerima isi kepercayaannya sebagai kebenaran." 9 Toleransi lebih merupakan suatu pemahaman dan praktek hidup yang perlu dikembangkan dan dipertahankan di tengah-tengah pluralitas bangsa Indonesia.

\footnotetext{
${ }^{6}$ Tanya, Pluralisme Agama ..., 13

7 Alister McGrath, A Passion for Truth The Intellectual Coherence Of Evangelicalism (Illinois: InterVarsity Press, 1996), 240

${ }^{8}$ Stevri Indra Lumintan, Re-Indonesianisasi Bangsa (Batu: Departemen MultiMedia YPPII, 2009), 618-619

${ }^{9}$ Henri Efferin, "Konsultasi Teologi," dalam Pelita Zaman (Jurnal) Vol. 16 no. $1,2001,89$
} 
Agama merupakan sebuah institusi yang sudah eksis dan berlangsung sejak lama, bahkan bisa disebut sama tuanya dengan manusia; ketika manusia diciptakan, manusia dapat berhubungan dengan sang Pencipta. Hubungan dengan Sang Pencipta inilah yang diyakini sebagai dasar dari agama. Pengertian dalam arah yang sama juga dikemukakan oleh W.S. Lasor : Religion may be defined as a relationship to the holy. ${ }^{10}$ Sedangkan A.K. Rule menjelaskan agama sebagai berikut: The acknowledgement of a higher, unseen power, an attitude of reverent dependence on that power in conduct of life; and special actions,eg., rites, prayers, and acts of mercy as peculiar expressions and means of cultivation of the religious attitude. ${ }^{11}$ Dengan demikian agama tidak dapat dipisahkan dari Pribadi yang Mahakuasa atau sang Pencipta. Dalam perjalanan waktu, sejalan dengan pertambahan umat manusia, agama menjadi kian beragam. Menurut Daniel Pals dari sekian banyak agama ada satu persamaan yang tidak dapat dipungkiri yakni, "Agama dasar" atau agama manapun terdiri atas kepercayaan pada Tuhan pencipta yang menjadikan dunia dan kemudian menyerahkannya pada hukum-hukum dasarnya sendiri. Suatu kode moral yang diberikan untuk membimbing manusia, dan janji akan kehidupan setelah mati jika mereka berbuat baik dan menghindari kejahatan. ${ }^{12}$ Pendapat Daniel Pals di atas tentu berbeda dengan doktrin Kristen di mana keagamaan yang diyakini adalah kehidupan yang didapatkan karena dan berdasarkan kedaulatan dan kasih Allah di dalam Kristus, bukan atas hasil suatu kode moral dan usaha sendiri atau sebuah hasil tindakan moral saja (Yoh 3:16). Manusia menemukan kebenaran yang telah dinyatakan oleh Pencipta-Nya. Kendatipun demikian tidak dapat dipungkiri bahwa agama juga memiliki peran yang penting, seperti yang dikemukakan oleh Victor Tanya bahwa agama adalah "Sebagai sistem kepercayaan dan peribadatan, agama berperan penting, dalam menciptakan tatanan kehidupan yang berkeadilan dan beradab bagi seluruh umat manusia di dunia." ${ }^{13}$ Secara umum agama memiliki tujuan agar tidak terjadi kekacauan bagi setiap pemeluknya.

10 W.S. Lasor, "Religions Of The Biblical World" dalam The International Standard Bible Encyclopedia, G.W. Bromiley (ed) (Grand Rapids, Michigan: Eerdmans, 1988), 79

11 A.K. Rule Religion,Religious dalam Evangelical Dictionary of Theology, Walter Elewll (ed) (Grand Rapids, Michigan: Baker Book House, 1984), 931

12 Daniel L. Pals, Seven Theories of Religions (Yogyakarta: Penerbit Qalam, 2001), 11

${ }^{13}$ Tanya. Pluralisme Agama..., xix. 
Dengan demikian jika berbicara mengenai toleransi beragama, berarti mengulas tentang sikap hidup manusia antar umat beragama, sikap yang terbuka dan secara dewasa menerima perbedaan agama-agama lain. Sikap yang ramah kepada sesama manusia tanpa mempersoalkan apa yang menjadi kepercayaannya. Pluralitas di Indonesia telah menciptakan kesadaran masyarakat yang toleran terhadap berbagai agama dan berbagai kepercayaan yang ada. Sikap toleransi sangat diperlukan untuk mencegah hal-hal yang tidak diinginkan. Namun demikian, sikap toleransi beragama seperti apa yang dapat dikembangkan dan dipertahankan dalam konteks pluralitas di Indonesia menurut keyakinan kristiani.

\section{DINAMIKA TOLERANSI BERAGAMA}

Bangsa Indonesia merupakan bangsa yang pluralitas dan telah terbiasa hidup dalam ke pelbagaian, sehingga masyarakat telah memiliki benih saling pengertian diantara penganut agama yang berbeda. Kendatipun demikian, tidak dapat disangkali bahwa toleransi beragama melahirkan dua kelompok, yaitu: Pertama, kaum fundamentalis, yakni orang atau kelompok yang memiliki visi untuk memulihkan dan/atau mempertahankan keyakinan agama, etnis, budaya, politik dan hukum sesuai dengan ajaran yang semula. Kelompok ini cenderung bersifat ekslusif, tidak terbuka dengan sesuatu di luar kelompok mereka, apalagi dengan kelompok di luar agama Islam. ${ }^{14}$ Sikap seperti itu dapat seringkali menimbulkan ketegangan diantara penganut agama. Adalah wajar jika penganut suatu agama menganggap ajaran agamanya adalah yang paling benar atau paling baik, Namun seiring dengan itu, harus pula disadari oleh setiap pemeluk agama bahwa penerapan sikap ini secara tidak proposional justru akan menimbulkan disharmoni bahkan konflik yang merugikan semua pihak, termasuk kelompok penganut agama tersebut. ${ }^{15}$ Kedua, ialah kelompok cinta damai di dalam semua agama, melakukan hal yang berbeda bahkan bertolak belakang, dengan yang dilakukan oleh kaum fundamental. Kaum pluralis justru mengakui semua agama sampai pada tingkat menerima kebenaran dari semua agama sebagai suatu kebenaran yang saling melengkapi. ${ }^{16}$

\footnotetext{
${ }^{14}$ Lumintang, Re-Indonesianisasi..., 502-510

${ }^{15}$ Tanya, Pluralisme Agama..., xix.

${ }^{16}$ Lumintang, Ibid..., 519
} 
Setiap kelompok agama memang harus dapat menguasai diri, dan memikirkan usaha-usaha untuk mencapai toleransi dan persatuan sebagai sesama warga Negara. Konflik antar umat beragama itu dapat terjadi karena beberapa hal, seperti yang dikemukakan oleh Makmur Halim, sebagai berikut:

(1) Konflik yang terjadi antar pengikut-pengikut secara individu dalam lingkup kecil atau sempit lingkungannya yang kemudian berkembang menjadi konflik antar kelompok; (2) Konflik yang terjadi antar tokoh-tokoh agama atau antar pemimpin-pemimpin agama yang berkembang menjadi konflik antar kelompok; (3) Konflik yang terjadi antar kelompok agama di negara-negara lain yang kemudian meluas ke konflik di negara sendiri; (4) Konflik yang terjadi antar kelompok agama dikarenakan adanya pihak ketiga atau pengadu domba, sehingga terjadi kemarahan satu sama lain antar kelompok agama; (5) Konflik yang terjadi oleh karena dari salah satu kelompok salah mengkomunikasikan berita, sehingga terjadi salah pengertian (miscommunication); (6) Konflik yang terjadi oleh karena propaganda atau penyiaran-penyiaran yang berbau keagamaan dan yang terlalu menonjol, dan akhirnya mengganggu dan menyinggung kelompok lain; (7) konflk yang terjadi oleh karena tidak ada pertemuan persahabatan antar kelompok umat beragama; (8) Konflik yang terjadi oleh karena terdapat konflik masa lalu atau luka lama yang belum selesai (unfinished business). Konflik ini bisa terjadi karena konflik yang terjadi dalam sejarah masa lalu; (9) Konflik yang terjadi antar kelompok agama disebabkan adanya kelompok agama yang salah dalam menggunakan atau menafsirkan ajaran-ajaran agamanya, sehingga menyerang kelompok agama lain. ${ }^{17}$

Konflik dapat terjadi karena berbagai faktor, baik yang bersifat internal, yakni dari kelompok agama itu sendiri maupun secara eksternal. Oleh sebab itu kelompok-kelompok umat beragama harus berhati-hati, dan dengan bijaksana membawa bendera agamanya masing-masing, serta menyaring informasi-informasi yang berkembang di tengah-tengah penganut agamanya masing-masing. Kesadaran bertoleransi hendaklah diupayakan dan diajar-ajarkan bagi seluruh warga Indonesia.

17 Makmur Halim, Gereja Di Tengah-Tengah Perubahan Dunia (Malang: Penerbit Gandum Mas, t.t.), 269-271 


\section{Urgensitas Toleransi Bergama}

Toleransi beragama merupakan hal yang amat penting dikembangkan di Negara Indonesia mengingat kepelbagaian agama yang ada di negara kita. Cooley memaparkan ada dua dasar serta dorongan dalam hal hubungan antar umat beragama yaitu: ${ }^{18}$

\section{Dorongan-dorongan Kuat Dari Luar}

Satu dorongan ialah adanya hubungan-hubungan tidak sehat, yakni hubungan antar umat beragama yang tidak menunjang perdamaian, keadilan serta pembangunan suatu dunia yang aman, makmur dan lestari itu yang sangat dirindukan oleh banyak orang di mana-mana di enam benua masa kini, khususnya mereka yang menderita. Dunia modern di mana-mana menampakkan adanya roh materialisme dan konsumerisme yang tidak kenal batas bersama dengan spekulasi beserta ketergantungan yang membahayakan pada super tekhnologi, baik dalam bidang produksi maupun bidang informasi. Roh-roh kemodernan tersebut dapat mengancam sifatsifat dasar dari kemanusiaan manuia. Manusia dijadikan barang, alat atau obyek belaka demi usaha mengumpulkan kekayaan materi atau kekuasaan tanpa batas. Kemodernan yang demikian, lebih jauh akan merusak nilainilai keagamaan/rohaniah bahkan eksistensi sendiri dari agama dalam kehidupan manusia pada masa mendatang. Oleh karena itu sangat diperlukan hubungan baik serta kerjasama yang erat dan aktif dari semua umat serta golongan beragama melawan arus keduniawian tersebut dan menyalurkan kearah yang dikehendaki Tuhan Yang maha Esa.

\section{Dorongan Dari Dalam Keagamaan Itu Sendiri}

Kendatipun penganut masing-masing agama cenderung memandang agamanya benar ataupun yang paling benar, namun akibat kenyataan bahwa semua agama dunia menganjurkan hubungan serasi dan baik antar umat beragama, pun sikap saling menghormati antar penganut agama-agama. Dalam Kitab suci agama Kristen terdapat ajaran-ajaran untuk berusaha membina hubungan baik dengan semua orang termasuk pemeluk agama lain. Misalnya hukum kasih (Mat 22:37-39 dan Yoh 15:12,17). Umat

${ }^{18}$ F.L. Cooley, Panggilan Umat Kristen Dalam Hubungan Antar Umat Beragama dalam Konteks berteologi di Indonesia. Penyunting Eka Darmaputera (Jakarta: BPK Gunung Mulia, 1991), 171-172 
Kristen harus berusaha memulihkan serta memperkuat hubungan baik dengan seluruh elemen umat beragama. Juga harus diusahakan oleh kedua belah pihak pembebasan dari semua ketidaktahuan (ignorance), paham serta sikap yang keliru (misunderstanding), polemik, prasangka (prejudices) serta ketakutan (fear) satu terhadap yang lain yang telah bertumbuh dan sengaja dipupuk selama masa lalu. Dan usaha tersebut dalam ukurannya bersifat monumental, raksasa, sangat berat dan memerlukan waktu yang lama. ${ }^{19}$ Dengan demikian toleransi beragama seharusnya bukan sekedar slogan semata-mata, namun menjadi suatu agenda yang amat penting untuk diperhatikan dan dikembangkan di dalam tatatan perilaku kehidupan masyrakat Indonesia yang majemuk ini.

\section{Pancasila Sebagai Dasar Negara Indonesia}

Sudah menjadi konsesus bangsa Indonesia menerima Pancasila sebagai satu-satunya asas dalam kehidupan bermasyarakat berbangsa dan bernegara. Itu berarti bahwa Pancasila-lah yang merupakan kaidah etika kita dalam kehidupan berbangsa dan bernegara, serta menjadi paradigma perilaku warga Negara Indonesia. Artinya Pancasila adalah design for living untuk bangsa Indonesia dalam rangka bermasyarakat, berbangsa dan bernegara. Untuk kita orang Kristen, Pancasila adalah norma untuk bermasyarakat, berbangsa dan bernegara, tetapi kita mengamalkannya di dalam ketaatan kita kepada norma agama, norma Injil yang mutlak. Itulah implikasi mengaku Kristus sebagai Tuhan dan Juruselamat. ${ }^{20}$ Pancasila telah memberi identitas kepada Indonesia, Pancasila merupakan ciri khas bangsa yang berbeda dibandingkan dengan masyarakat, bangsa lain. Sebagai dasar Negara, Pancasila tercantum dalam UUD 45. Bahkan dalam UUD pasal 29: 1 dijelaskan "Negara berdasarkan Ketuhanan yang Maha Esa." Walaupun demikian Negara Pancasila bukanlah negara agama dan bukan pula negara sekuler. Negara Pancasila tidak mengenal "negara agama," maupun "agama Negara." Tidak ada agama, paling sedikit secara konstitusional, yang mempunyai "status lebih" atau "status kurang" dibandingkan dengan yang lain. Tidak ada mayoritas maupun minoritas di dalam hak dan kewajiban. Dengan demikian, maka kenyataan kemajemukan agama diakui keabsahan eksistensinya. UUD pasal $29: 2$

${ }^{19}$ Cooley, Panggilan Umat Kristen..., 172

${ }^{20}$ Theo Kobong, "Iman Kristen dan Pancasila" dalam Teologi Perjumpaan, Phil. J. Garang \& Weinata Sairin (peny.), (Jakarta: Badan Penelitian dan Pengembangan Persekutuan Gereja-Gereja di Indonesia, 1993), 216 
tidak hanya (secara pasif) mengakui kenyataan kemajemukan agama, tetapi juga (secara aktif) menjamin kebebasan beragama setiap penduduk Indonesia. Pancasila menjamin kebebasan kelima agama menjalankan ajaran dan kepercayaan mereka, tanpa campur tangan pemerintah. Namun demikian, di dalam Negara Pancasila, kebebasan tidak boleh diartikan kebebasan tanpa batas. Kebebasan harus diletakkan di dalam kerangka dan batas kesatuan serta persatuan bangsa, yang menjadi salah satu sendi utama dari jiwa Pancasila itu sendiri. Karena itu, prinsip kebebasan beragama bukanlah prinsip satu-satunya. Prinsip tersebut berdampingan dan bertalian erat dengan prinsip kerukunan beragama, atau kerukunan umat beragama. ${ }^{21}$

\section{Keunikan Pluralitas}

Pluralitas dan Pluralisme merupakan dua hal yang berbeda. Pluralitas agama merupakan kepelbagaian agama namun pengertian pluralitas tidak sama dengan kemajemukan. Pluralitas mengacu pada adanya hubungan saling bergantung antar berbagai hal yang berbeda, sedang kemajemukan (diversitas) mengacu kepada tidak adanya hubungan seperti itu diantara hal-hal yang berbeda. Dengan demikian, pluralitas mengharuskan adanya dialog antar semua umat beragama. Dalam dialog itu, faktor etika sangat menentukan karena menyangkut masalah bagaimana seseorang bersikap terhadap sesamanya. ${ }^{22}$

Dalam perjalanan umat manusia, agama-agama menjadi sumber motivasi dan inspirasi yang tidak pernah kering. Satu hal yang menjadi tantangan dalam pluralitas agama ialah pemeluk agama memiliki klaimnya masing-masing mengenai kebenaran absolut yang diimani dan diamini. Hal ini tentu sangat berpotensi untuk melahirkan fanatisme terhadap agama sendiri, dan antipati terhadap orang yang memeluk agama lain. ${ }^{23}$ Tentu saja hal ini dapat dicegah jika umat beragama dengan bijaksana bersikap toleran terhadap semua agama di Indonesia. Sikap toleran menghasilkan kerukunan umat beragama di bumi pertiwi ini.

${ }^{21}$ Eka Darmaputera, Pergumulan Dan Peran Gereja Dalam Masyarakat Dan Negara Pancasila dalam Gerakan Oikoumene Tegar Mekar Di bumi Pancasila (Jakarta: BPK Gunung Mulia,1993), 310-311.

${ }^{22}$ Tanya, Pluralisme Agama..., 4

${ }^{23}$ Lumintang, Re-Indonesianisasi ..., 519 


\section{Tantangan Pluralisme}

Pluralisme seperti yang telah dikemukakan di atas justru mengakui semua agama sampai pada tingkat menerima kebenaran dari semua agama sebagai suatu kebenaran yang saling melengkapi. ${ }^{24}$ Pluralisme keagamaan pada pihak lain, adalah kepercayaan bahwa perbedaan-perbedaan antara agama-agama adalah bukan masalah kebenaran dan ketidakbenaran, tetapi tentang perbedaan persepsi terhadap satu kebenaran; ini berarti bahwa berbicara tentang kepercayaan-kepercayaan keagamaan sebagai benar atau salah tidak dapat diperkenakan. ${ }^{25}$ Dalam arah yang sama Gary Phillips memberikan tiga hal tentang terminology pluralisme, yakni: (1) the growing diversity of race, heritage, religion, and value systems within Western culture; and (2) the value of toleration for this diversity. (3) the philosophical posture which insists that tolerance must be granted to all views on the ground that none can claim to be true. ${ }^{26}$ Dalam terminologi yang satu ini perlu juga dibedakan antara pluralisme kebudayaan dan pluralisme keagamaan. Tentu saja benar bahwa kebudayaan dan agama saling berkaitan erat. Agama dari satu sudut pandang adalah aspek dari kebudayaan, tetapi kebudayaan ini bukanlah keseluruhan agama itu. Agama-agama dapat bersifat multikultural, seperti yang nyata dalam kekristenan. ${ }^{27}$ Pluralisme adalah suatu tantangan sekaligus bahaya yang sangat serius bagi kekristenan. Karena pluralisme bukanlah sekedar suatu konsep sosiologis, antrophologis, melainkan konsep filsafat agama yang bertolak bukan dari Alkitab, melainkan bertolak dari fakta kemajemukan yang diikuti oleh tuntutan toleransi, dan diilhami oleh keadaan sosialpolitik yang didukung oleh kemajemukan etnis, budaya dan agama; serta disponsori oleh semangat globalisasi dan filsafat relativisme yang mengiringinya. ${ }^{28}$

Maka itu bagi kaum pluralis, yang dibutuhkan bukanlah kristologi, soteriologi dan pneumatologi, melainkan teologi agama-agama atau teologi abu-abu (pluralisme). Para penganut pluralisme memang tidak meniadakan doktrin-doktrin Kristen, juga tidak menyatukan semua doktrin yang ada di semua agama, namun mengembangkan doktrin masing-masing agama

\footnotetext{
${ }^{24}$ Lumintang, Re-Indonesianisasi ..., 519

${ }^{25}$ Lesslie Newbigin, Injil Dalam Masyarakat Majemuk (Jakarta: BPK Gunung Mulia 1993), 20

${ }^{26}$ Gary Phillips, "Religious Pluralism In A Postmodern World" in The Challenge of Post Modernism, David S. Dockery (ed.). (Grand Rapids, Michigan: Baker Academic, 2001), 135

${ }^{27}$ Ibid., 19

${ }^{28}$ Lumintang, Ibid., 521
} 
dengan cara membuka diri terhadap pengadopsian kebenaran doktrin agama lain. ${ }^{29}$ Berkaitan dengan hal itu, Darmaputera mengemukakan bahwa "satu hal yang patut disadari dan dilakukan oleh masing-masing pemeluk agama ialah masing-masing agama berupaya sekuat-kuatnya menahan diri, bertenggang rasa, peka terhadap perasaan kelompok yang lain, dengan tanpa menghianati pokok-pokok ajaran agamanya sendiri." 30

\section{MOTIF MISI KRISTEN}

Misi Kristen adalah misi yang lahir dari Allah. Allah terlebih dahulu telah melakukan misi itu sendiri dengan mengutus Yesus Kristus ke dalam dunia. Tuhan Yesus sebelum naik ke surga memandatkan para murid-Nya untuk meneruskan misi yang telah dimulai oleh-Nya; seperti yang dicatat dalam Matius 28:19-20. Untuk itu misi Kristen selayaknya memiliki motivasi yang selaras dengan maksud Allah yang mula-mula. Beberapa motif misi Kristen yang harus diperhatikan yakni:

\section{Motif Kedaulatan Allah}

Kedaulatan Allah tidak meniadakan peran dan tanggungjawab manusia, tidak ada pertentangan diantaranya. Kedaulatan Allah memberi nilai bagi tanggungjawab manusia. Manusia bertanggung jawab karena telah terlebih dahulu mengalami pembaruan oleh Roh Kudus, menghidupkan dan memberdayakan manusia secara total. Buah kelahiran kembali memungkinkan manusia mengalami pertobatan, iman, pembenaran, pengudusan dan ketaatan. $^{31}$ Karya Roh Kudus yang memampukan orang percaya untuk taat. Ada beberapa motif yang digerakkan oleh kedaulatan Allah, yaitu: Pertama, kedaulatan Allah dalam misi membuat orang percaya menjadi lebih agresif dalam melaksanakan misi. Atas dasar, bahwa tujuan penginjilan adalah untuk mempertobatkan pendengar kepada Kristus. ${ }^{32}$ Adalah hal yang benar ketika kita mengakui tanggungjawab kita untuk menginjili secara agresif, menginginkan

\footnotetext{
2003), 36

32 J.I. Packer, Evangelism and The Sovereignty of God (Surabaya: Momentum,
}

${ }^{29}$ Lumintang, Re-Indonesianisasi ..., 522-523

${ }^{30}$ Darmaputera, Pergumulan Peran Gereja..., 311

${ }^{31}$ Anthony A. Hoekama, Save By Grace (Grand Rapids, Michigan: Eerdmans, 1994), 94 
pertobatan orang yang belum percaya, dan menghendaki penyampaian berita Injil sejelas dan sekuat mungkin. Jika kita tidak peduli apakah penginjilan kita itu akan menghasilkan sedikit atau banyak petobat baru, apakah pemberitaan kita tentang Kristus mengenai sasaran atau tidak, maka ada sesuatu yang salah pada kita. Tetapi sama salahnya jika kita mengambil tangung jawab lebih dari yang Allah berikan. ${ }^{33}$ Kedaulatan Allah dalam anugerah memberikan satu-satunya pengharapan atas keberhasilan dalam penginjilan. Kedaulatan Allah dalam anugerah merupakan satu-satunya hal yang mencegah penginjilan menjadi sia-sia dan menciptakan kemungkinan atau kepastian bahwa penginjilan akan menghasilkan buah. ${ }^{34}$ Karena buah penginjilan, yaitu pertobatan orang berdosa kepada Kristus. Pertobatan itu adalah pekerjaan Allah yang berdaulat. Efektivitas penginjilan juga bergantung kepada Injil yang berkuasa, karena Injil adalah kekuatan Allah yang menyelamatan setiap orang yang percaya ( $\mathrm{Rm} 1: 16)$ melalui pekerjaan Roh Kudus. Kedua, Kedaulatan Allah dalam pelaksanaan misi dan penginjilan akan membangkitkan dan memurnikan motif-motif misi dan penginjilan. Motif-motif misi adalah berakar pada maksud dan tujuan misi. Jika Gereja mengandalkan kedaulatan Allah dalam pelaksanaan misi, maka motif misi adalah bersifat theo-sentris. Semua konsep dan praktek misi berpusat bukan pada kemampuan manusia, dan bukan demi kepentingan manusia, melainkan berpusat pada Allah dan demi kemuliaan-Nya. ${ }^{35}$

\section{Motif Kristus (Salib)}

Misi Kristen di seluruh dunia adalah milik Kristus, bukan milik Gereja. Sebelum segala usaha dan aktivitas Gereja, sebelum semua persembahan berupa pelayanan dan pengabdian, Allah mengirim Anak-Nya ke dalam dunia, dan Ia datang dalam diri seorang hamba yang menderita bahkan sampai mati pada Salib. Keyakinan ini merupakan satu-satunya motif sejati dari misi Kristen serta satu-satunya standar yang dengannya semangat, metode, dan cara-cara organisasi misi Kristen harus dinilai. Adalah merupakan tugas yang mendesak bahwa firman tentang penghakiman dan belas kasih ini harus diberi kebebasan penuh untuk membersihkan dan menebus aktivitas-aktivitas Gereja sekarang ini, agar

\footnotetext{
${ }^{33}$ Ibid., 18

${ }^{34}$ Ibid., 86

${ }^{35}$ Lumintang, Misiologia Kontemporer..., 264
} 
kesombongan manusiawi kita dalam aktivitas-aktivitas kita tidak menghalangi jalan misi Allah di dalam dunia. ${ }^{36}$

\section{Motif Kemuliaan Allah}

Misi Gereja adalah dimulai dari hati Allah yang terdalam (Missio Dei). Karena semua aktivitas misi adalah dari Allah, oleh Allah dan untuk Allah saja. Misi Gereja bukanlah milik Gereja, melainkan milik Allah. Karena itu, kepada Allah jugalah kemuliaan misi yang dilaksanakan oleh Gereja dalam dunia. Namun, pada masa kini fokus misi telah bergeser, sehingga misi dipandang sebagai milik Gereja.

Kaum Pluralis menyuarakan dan mencari misi Allah di luar tradisi Kristen, yaitu di luar Alkitab. Mereka berusaha mencari misi Allah yang ada dalam kebudayaan dan agama-agama lain, melalui dialog. Dengan meninggalkan Alkitab sebagai sumber utama teologi misi. Ken Gnanakan mengungkapkan beberapa pertanyaan yang esensial mengeni misi, untuk mengevaluasi misi Gereja masa kini, diantaranya ialah: Apakah dan bagaimanakah misi yang alkitabiah? Apakah misi Allah itu? Apakah keunikan berita Injil? Apa bedanya misi Gereja masa lalu dan masa kini? ${ }^{37}$ Jawaban atas pertanyaan ini adalah misi bersumber pada misi Allah Tritunggal di dalam dan melalui Gereja, dan hakekat Gereja itu sendiri. Kristus adalah kepala Gereja, karena itu misi Gereja (missio ecclesiae) haruslah dievaluasi oleh misi Kristus (missio Kristie). Misi Gereja bersumber dan berpusat serta bermuara pada misi Kristus. ${ }^{38}$ Misi berpusat bukan kepada kemampuan manusia, melainkan berpusat pada Allah dan kemuliaan-Nya. Berkaitan dengan hal itu Bavinck mengatakan, bahwa Kedatangan kerajaan itu adalah berkenaan dengan Allah, dengan kebesaran-Nya, kehormatan dan anugerah-Nya. Kedatangan kerajaan Allah termasuk dengan perluasan Gereja di seluruh wilayah di dunia ini. Dan kedatangan kerajaan Allah merealisasikan diri-Nya dalam pertobatan orang-orang berdosa. Ada tiga tujuan yang terpisah, namun ada satu tujuan yang terbesar dan final, itu disingkapkan kepada kita dalam berkat, pertama: pemuliaan Allah merupakan tujuan terutama; kedua ialah penanaman Gereja; dan yang ketiga ialah pertobatan orang-orang

\footnotetext{
${ }^{36}$ Cuplikan dari International Missionary Council (Ghana, 28 Desember 1957-7 Januari 1958), Minutes of the Assembly (London dan New York: IMC, 1958), 89

${ }^{37}$ Ken Gnanakan, Kingdom Concern: A Biblical Exploration Toward a Theology of Mission (Banglore: Theological Book Trust, 1997), 23

${ }^{38}$ Lumintang, Misiologia Kontemporer ..., 129
} 
penyembahan berhala. Kemuliaan Allah diajarkan oleh Alkitab berkali-kali sebagai tujuan yang tertinggi. ${ }^{39}$ Kemuliaan Allah merupakan motif misi, baik dalam rangka membangkitkan semangat misi maupun dalam rangka memurnikan semua motif dari pemahaman dan praktek misi dari semua yang bersifat manipulasi yang tidak memahami toleransi.

\section{Motif Misi Kristus Menjadi Model Misi Gereja}

Tuhan Yesus berkata: "Damai sejahtera bagimu! Seperti Bapa telah mengutus Aku, demikian Aku mengutus kamu." Dan kemudian Ia mengembusi mereka dan berkata: "terimalah Roh Kudus" (Yoh 20:21-22). Ada tiga hal yang menjadi inti berita, yaitu: Pertama, bahwa misi Allah Bapa juga merupakan misi Allah Anak. Hal ini tentu bertentangan dengan konsep Pluralisme yang menolak Kristus sebagai pusat Kerajaan Allah, dan membedakan Kerajaan Allah Bapa dengan Kerajaan Allah Anak. Ini tentu merupakan kesalahan dan kelemahan yang fatal dari konsep theocentric kaum Pluralis dalam penafsiran Injil. Kedua, Allah Tritunggal yang mengutus Gereja ke dalam dunia ini dengan otoritas Allah sendiri (Yoh 20:21-22). Ketiga, bahwa misi Allah adalah misi Allah Bapa, Allah Anak, dan Allah Roh Kudus. Hal ini juga memberikan pola bagi Gereja, bahwa misi Allah Tritunggal merupakan model misi Gereja dalam dunia. ${ }^{40}$ Berkaitan dengan misi Gereja tersebut Stott memberi komentar, bahwa: "Ketika Anak Allah diutus ke dalam dunia, Ia tidak tinggal jauh dari penderitaan dan kesaksian, melainkan, Ia masuk ke dalam dunia manusia melalui menjadi menusia atau berinkarnasi. Dengan Ia menjadi manusia, Ia menjadi manusia yang dapat mengalami pencobaan dan penderitaan." Bertolak dari pengertian tersebut, Stott kemudian menjelaskan tugas Gereja menurut penjelasan Rlph Winter mengenai tiga jenis penginjilan, yaitu: "E1 (dalam kebudayaan dan bahasa kita sendiri), E-2 (mencapai orang yang bahasa dan budayanya adalah sama), dan E-3 (penginjilan lintas budaya)."41 Tugas Gereja adalah melintasi kebudayaan apapun yang ada dalam dunia dan hadir di dalamnya, sebagaimana Kristus datang dan tinggal dalam dunia. Inilah model misi inkarnatif.

\footnotetext{
39 J.H. Bavinck, An Introduction to the Science of Mission (Phillipsburg, New Jersey: Presbyterian and Reformd Publishing Co, 1960), 155-156

${ }^{40}$ Lumintang, Misiologia Kontemporer ..., 130

41 Joh Stott, Making Christ Known: Historic Mission Document from the Lausanne Movement 1974-1989 (London: Paternoster Press, 1988), 29
} 
Misi haruslah didasarkan pada misi inkarnasi Yesus Kristus, yaitu ketika Ia menjadi manusia, Ia datang melintasi dan tinggal dalam kebudayaan manusia. Inkarnasi Kristus merupakan suatu model bagi misi Gereja. Allah Bapa mengutus Anak-Nya ke dalam dunia, dan sekarang Yesus mengutus Gereja-Nya ke dalam dunia, dengan model pengutusan Allah Bapa atas-Nya. Berkaitan dengan hal itu, Stott menjelaskan bahwa "memang semua misi yang otentik adalah misi inkarnatif. Itu artinya masuk kedunia orang yang lain, yang berbeda, seperti Ia masuk ke dalam dunia kita. Misi yang demikian merupakan misi kontekstual yang menuntut identifikasi diri tanpa kehilangan identitas. Itu berarti masuk ke dalam dunia manusia, seperti Ia masuk ke dalam dunia kita, walaupun tanpa mengkompromikan keyakinan, nilai-nilai, dan standar kehidupan Kristen." ${ }^{42}$ Oleh karena itu, Gereja harus kembali kepada Alkitab sebagai dasar dan sumber serta motif misi Gereja. Teologi misi apapun yang dihasilkan pada masa kini, harus mencari dan menemukan misi Allah dari kesaksian Alkitab. Misi di luar data dan pemahaman Alkitab adalah missing. ${ }^{43}$

Dengan demikian ada dua motif utama dalam pergerakan misi dan penginjilan Gereja, yaitu: Pertama adalah motif primer dan fundamental. Tujuan akhir manusia adalah memuliakan Allah. Hukum kehidupan dalam Alkitab adalah: "Lakukanlah semuanya itu untuk kemuliaan Allah" (1Kor 10:31). Manusia memuliakan Allah dengan menaati Firman-Nya dan memenuhi kehendak-Nya yang diwahyukan. Begitu juga perintah pertama dan terutama adalah "kasihilah Tuhan, Allahmu." Kita menunjukkan kasih kepada Bapa dan Anak yang telah begitu mengasihi kita dengan cara menaati perintah-Nya. Motif kedua yang seharusnya mendorong penginjilan kita adalah kasih kepada sesama manusia dan kerinduan untuk melihat mereka diselamatkan. Hasrat untuk memenangkan yang terhilang bagi Kristus seharusnya merupakan ekspresi alamiah dan spontan dari kasih yang mengalir dalam setiap hati orang yang telah lahir baru. ${ }^{44}$

\section{Toleransi Agama dan Misi Dialogis Kristen}

Apakah toleransi bertentangan dengan amanat penginjilan? Tentu penginjilan bukanlah pengkristenan seperti yang dipraktekkan oleh sebagian orang Kristen dan seperti yang dianggap dan dituduhkan oleh

\footnotetext{
${ }^{42}$ John Stott, The Contemporary Christian (Leicester: Inter-Varsity, 1992), 358

${ }^{43}$ Lumintang, Misiologia Kontemporer ..., 129

${ }^{44}$ Packer, Evangelism and the Soverignty..., 58-59
} 
beberapa kalangan masyarakat. Pengkristenan selalu dihubungkan dengan imperialisme Barat pada masa lampau, yang sering memanipulsi pelbagai cara untuk membuat orang menjadi Kristen tanpa mengalami atau memiliki unsur pertobatan. Sedangkan penginjilan merupakan pemberitaan Injil, Kabar Baik kepada semua orang. Persoalan antara pengkristenan dan penginjilan adalah persoalan yang berkaitan dengan metode. Karena itu, tanpa merusak semangat toleransi, pastinya penginjilan dalam pendekatanpendekatan manusiawi dan tanpa memanipulasi segala cara untuk mendapatkan hasil. Penginjilan seperti itu, tentu bukan lagi penginjilan yang dimaksud oleh Alkitab. Karena penginjilan manipulatif, yang bermuatan paksaan, hipnotis, rayuan dan sebagainya, sesungguhnya bertentangan dengan hakekat Injil yang berkuasa dari Injil itu sendiri. Sehingga tidak perlu cara-cara yang tidak sehat, yang disadari atau tidak merendahkan kuasa Injil. Dan orang yang mengalami kuasa Injil, tentu tidak mungkin berdiam diri, kecuali mereka adalah kaum pluralis, yang memang tidak mengakui dan percaya kepada Injil lagi. ${ }^{45}$

Dialog berarti komunikasi dua arah. Secara teologis dialog dapat dipahami berdasarkan Missio Dei, Allah mengutus Yesus Kristus untuk berkomunikasi dengan manusia (dialog). Inkarnasi Yesus Kristus membuktikan bahwa Allah berkomunikasi dengan dunia (manusia), namun bukan ini tujuan akhirnya, melainkan menyelamatkan manusia di dalam dan melalui karya Kristus. Dengan demikian fokus dari dialog antar umat beragama adalah memberikan kontribusi kepada masyarakat melalui Injil yang membaharui. Kerjasama akan membangun masyarakat yang berbudaya akan terfokus kepada praktik-praktik dari ajaran agama masingmasing, dan praktik ini bertemu di dalam kehidupan masyarakat secara langsung. Hasilnya adalah, bahwa dialog yang berdasarkan membawa sesuatu yang bisa dinikmati oleh masyarakat dan membalut luka-luka lama yang masih ada.

\section{PENUTUP: KESIMPULAN}

Indonesia adalah negara yang kaya. Ada beribu-ribu pulau, banyak budaya dan bahasa, bahkan terdapat berbagai agama dan kepercayaan terhadap Tuhan yang Mahaesa di bumi pertiwi ini. Toleransi beragama merupakan suatu agenda yang penting mengingat pluralitas agama yang ada di negara kita. Sebagai kaum Injili kita juga turut andil dalam toleransi

\footnotetext{
${ }^{45}$ Henry Effrerin, “Konsultasi Teologi,” Pelita Zaman, Vol 16 no.1, 2001, 90
} 
agama dengan memberikan wawasan Alkitabiah toleransi agama serta memberi wawasan kebangsaan yang berjiwa Pancasila pada jemaat. Di samping itu kita juga harus mengagendakan upaya dialog antar umat beragama.

Kemajemukan agama merupakan fakta keragaman bangsa Indonesia yang harus diterima dan disyukuri sebagai bagian dari kehendak Tuhan sendiri. Pluralitas tidak perlu diperdebatkan dan dieksploitasi sebagai sarana menggugat kelompok-kelompok tertentu atau bahkan disingkirkan demi supremasi dan kepentingan politik dan agama tertentu. Sebagai pengikut Kristus kita harus proaktif dalam mengupayakan terjadinya toleransi beragama di negeri ini. Upaya dan kerja keras sangat dibutuhkan mengingat ancaman disintegrasi bangsa. Pluralitas agama disatu pihak merupakan kekayaan dan keunikan bangsa Indonesia yang tidak dapat dipungkiri. Hal ini harus disikapi dengan bijak, agar masyarakat Indonesia dapat hidup dengan damai di negeri yang tercinta ini. Hendaknya toleransi tidak sekedar menjadi suatu wacana saja tetapi harus teraplikasi dalam kehidupan sehari-hari.

Tidak dapat dipungkiri bahwa misi Kristen merupakan bukti keberadaan Kekristenan di dunia pada umumnya serta di Indonesia ini. Penginjilan yang memberi tempat pada kejujuran dan tanpa melukai atau merendahkan agama lain. Kemajemukan masyarakat di tengah-tengah pluralitas agama dan kebudayaan adalah perilaku yang harus di responi dengan sikap toleransi. Semua agama memiliki kedudukan yang sama di bumi pertiwi ini sesuai dengan dasar Negara Pancasila. Misi Kristen merupakan satu wujud keunikan iman Kristiani tanpa melupakan fakta adanya penganut agama lain, serta tanpa kehilangan identitas misi Kristen yang bersifat Misio Dei, yang turut memberi sumbangsih bagi kesejahteraan bangsa. Maka tidaklah dapat diragukan lagi misi Kristen merupakan hal yang sangat penting bagi kekristenan di masa mendatang. 